\title{
A Study on the Voltage Regulation Method Based on Artificial Neural Networks for Distribution Systems Interconnected with Distributed Generation
}

\author{
Rho, Daeseok $^{1^{*}}$ and Euihwan Kim ${ }^{2}$ \\ ${ }^{1}$ Dept. of Electrical Engineering, Korea University of Technology and Education, ${ }^{2}$ KEPRI \\ 분산전원이 연계된 배전계통에 있어서 $\mathrm{ANN}$ 을 이용한 최적 \\ 전압조정방안에 관한 연구 \\ 노대석 ${ }^{*}$, 김의환 $^{2}$ \\ ${ }^{1}$ 한국기술교육대 정보기술공학부, ${ }^{2}$ 한전전력연구원
}

\begin{abstract}
This paper deals with the optimal on-line real time voltage regulation methods in power distribution systems interconnected with the Distributed Generation(DG) systems. In order to deliver suitable voltage to as many customers as possible, the optimal sending voltage should be decided by the effective voltage regulation method by using artificial neural networks to consider the rapid load variation and random operation characteristics of DG systems. The results from a case study show that the proposed method can be a practical tool for the voltage regulation in distribution systems including many DG systems.
\end{abstract}

요 약 본 논문은 분산전원이 연계된 배전계통에 있어서 온 라인 리얼타임으로 조정이 가능한 최적 전압조정방안을 제시한다. 가능한 많은 수용가에게 적정한 전압을 공급하기 위하여 최적 송출전압이 결정되어져야 하는데, 여기서는 급변하는 배전계통의 급격한 부하변동과 분산전원의 불규칙적인 출력특성을 고려하기 위하여, 인공 신경회로망(ANN: Artificial Neural Network)을 이용한 최적 전압조정방안을 제시한다. 본 논문에서 제시한 알고리즘을 이용하여 배전 모델계통에 적용한 결과, 제안한 방법이 다수의 분산전원이 연계된 배전계통의 전압조정에 실용적인 방책임을 확인하 였다.

Key Words : Distribution systems, Voltage regulation, Distributed Generation, Artificial neural network

\section{Introduction}

With the development of industry and the improvement of living standards, better quality in power electric service is required more than ever before. Also, as one of the countermeasures against daily load factors worsening and global environmental issues, DG systems such as photovoltaic cells, fuel cells and secondary battery storage, are being interconnected with power distribution systems. Under these circumstances, to deliver reasonable voltage to as many customers as possible, optimal voltage regulation methods in distribution systems need to be developed.

The Bank Line Drop Compensation (LDC) method is currently used at many utilities to maintain customer voltages within the allowable limits $(220 \pm 6 \%)$ as shown in Refs. [1] [6]. The method is based on the concept of an imaginary standard feeder to represent total feeder characteristics. However, the determination of LDC setting values with the imaginary standard feeder configurations, is difficult. Futhermore, DG systems interconnected with distribution systems make voltage regulation very complicated.

In this paper, an real time voltage regulation method using

${ }^{*}$ Corresponding Author : Rho, Daeseok(dsrho@kut.ac.kr) 
neural networks trained by error back propagation algorithm is presented to consider the rapid load variations and the random operation characteristics of DG systems. Numerical examples are shown in order to verify the efficiency of the proposed method.

\section{Existing(Modified) Voltage Regulation Method}

The decision problem of optimal sending voltages at voltage regulator of Load-Ratio control Transformer(LRT) by the LDC method as shown in Fig. 1 is to find the optimal LDC setting values to deliver suitable voltages to as many customers as possible. The modified method as shown in Refs [7] \& [8] firstly determines ideal optimal sending voltages based on the existing LDC method, and then obtains optimal setting values by the statistical analysis according to the relationship between idea optimal sending voltages and total load currents. The method presents the idea that for the worst conditioned case having the biggest voltage drop and a severe voltage fluctuation, if all customers throughout this feeder are to be maintained within the allowable voltage limits and also have reasonable voltage distributions.

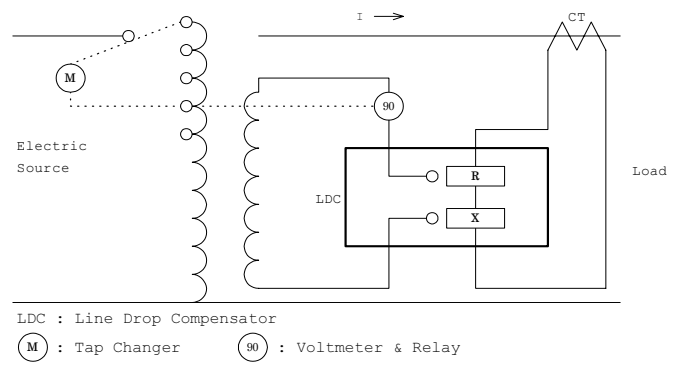

[Fig.1] Concepts for LDC methods

\section{On-line Real Time Voltage Regulation Method Using Neural Networks}

The existing(modified) LDC method as shown in Refs. [7], [8] are not suitable for consideration of the rapid load pattern variations and radon operation characteristics of DG systems because these methods are basically operated with the same LDC setting values for a long real time period once they are fixed. An on-line real time voltage regulation method whose LDC setting values are appropriately decided by the load variations is desirable for solving those problems. However, it requires computational burden and a large quantity of on-line measurement data as shown in Ref. [7].

This paper proposes an on-line real time voltage regulation method using artificial neural networks (ANN), since the voltage regulation method is considered as the pattern recognition problem. This proposed method can be expected to reduce the computational burden and telemetering devices by using only the measurement data of active power at each feeder. Generally, ANN shows the error robustness and provides satisfactory solutions based on the trained knowledge. Also, ANN has the capability of fast data processing by parallel processing. $\mathrm{ANN}$ is designed to improve the voltage compensation capability of LRT. It dynamically determines the most appropriate LDC setting values by recognizing the load pattern and operation pattern of DG systems for each time period.

\subsection{Artificial Neural Networks}

This study adopts the multi-layer feedforward machine of Rumelhart et. al in Refs. [9] [12]. The model is trained by error back propagation algorithm and adjustment process of interconnecting weights(Wi) and $\operatorname{thresholds}(\theta)$ is repeated until the recognition capability is obtained. The input and output relationship of multi-layer perceptron is represented as eq. (1).

$$
y=f\left(\sum_{i=0}^{N-1} W_{i} \cdot X_{i}(t)-\theta\right)
$$

where, $\mathrm{y}$ : output value, $\mathrm{Xi}$ : input value, Wi : weighting factor, $\Theta$ : threshold value, $\mathrm{N}$ : layer number, $\mathrm{f}:$ nonlinear function And, the improvement algorithm for weighting factor based on the generalized delta rule is as follows :

$$
\triangle_{p} W_{j i}=\eta\left(t_{p j}-o_{p j}\right) i_{p_{i}}=\eta \delta_{p j} i_{p_{i}}
$$

where, $\dot{n}$ : learning rate, $t_{\mathrm{pj}}: \mathrm{j}$ component of pth target output pattern, $\mathrm{O}_{\mathrm{pj}}: \mathrm{j}$ component of $\mathrm{pth}$ real(computed) output pattern, $\mathrm{i}_{\mathrm{pi}}$ : $\mathrm{i}$ component of $\mathrm{pth}$ input pattern, $\delta_{\mathrm{pj}}$ : error of target and real output. 


\subsection{Design of ANN Structure}

A separate-type neural network model for the determination of the LDC setting values is designed as shown in Fig. 2, to consider the load variation as well as the operation characteristics of DG systems. Atotal of $n$ neural networks are built to consider the operation patterns of DG systems, which are divided into $\mathrm{n}$ levels such as $0 \%, 25 \%$, $50 \%, 75 \%$ and $100 \%$ based on the rated output of DGS systems.

The individual neural network, ANNs, has input units. 25 hidden units and 7 output units through learning experience, and determines the equivalent impedance $Z s$ for $s=1,2, \ldots ., n$ with the input Itotal, $\mathrm{Pt}$ for $\mathrm{t}=1,2, \ldots . . \mathrm{g}$. Itotal, $\mathrm{Pt}$ and $\mathrm{g}$ are the total current of the LRT, active power and total feeder number, respectively. If the impedance is divided into $\mathrm{k}$ levels, the total number of output units in ANNs is k. Thus, the individual neural network determines the appropriate impedance by outputting 1 for the unit with the most similar load pattern to that given, and 0 for the other units. Then, the neural network output corresponding to the operation patterns of DG systems is decided, which is the impedance of the LDC setting values,

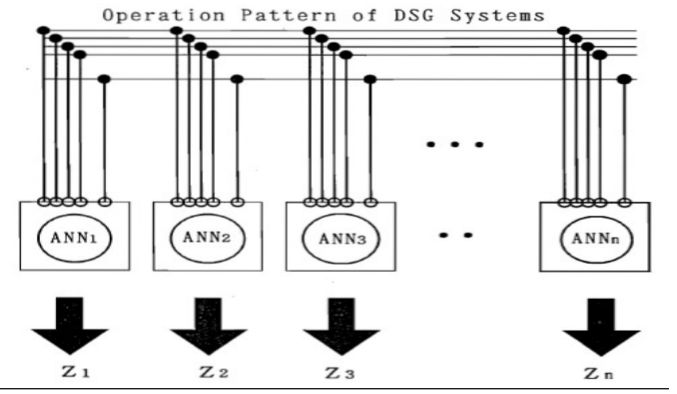

[Fig.2] Design of separate-type ANN model

Therefore, an outline of the on-line real time voltage regulation using the neural networks can be shown in the from as given in Fig. 3. The dotted lines are the information flow of on-line real time control.

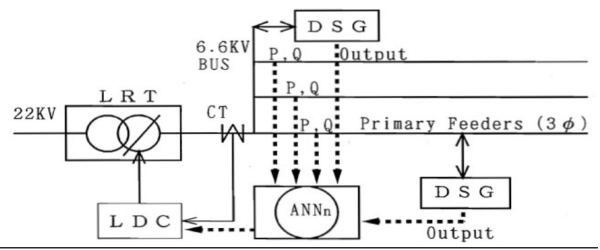

[Fig.3] On-line real time method using neural networks

\subsection{Training Set Build-up}

The pattern recognition capability of neural networks is dependent upon the quantity and quality of the training set within the possible learning boundary, the type and magnitude of the section load in a distribution system should be appropriately divided. For the levels W, P of the load type and magnitude, respectively, the number of ANNs training patterns becomes Pw. The load types are classified into three groups such as the residential (R), the commercial (C) and the industrial (I). The load magnitudes are also divided into 4 levels, $100 \%, 80 \%, 60 \%$ and $40 \%$ on the basis of peak load. We now describe the building procedure of the ANNs training set in the following:

[step1] For n-Pw load level combinations, execute the load flow solutions. Also, calculate the total load current of LRT, the feeder active and reactive powers, the customer voltages of all nodes, and the optimal sending voltage for each time period.

[step2] For $\mathrm{n}-\mathrm{Pw}$ load patterns, calculate the equivalent impedance corresponding to the load center voltage which is provided by experience.

[step3] Divide the impedance of [step2] into $\mathrm{k}$ levels between the minimum and the maximum.

[step4] Obtain the knowledge patterns with the values of [step1] as the input pattern and the values of [step3] as the output pattern. Then, divide the knowledge patterns into $\mathrm{n}$ operation patterns of DG systems, and build $\mathrm{n}$ training sets for ANNs, $\mathrm{s}=1,2, \ldots \ldots, \mathrm{n}$.

\subsection{Neural Network Models}

In this paper, 2 types of neural network models are presented to evaluate the pattern recognition capability. One is a separate-type neural network model as shown in Fig. 2 and the other is a single-type model. The latter has one neural network and considers the operation pattern of DG systems as a unit of input patterns. Table 1 shows the experimental conditions of the models. ANNs training of the separate-type model requires approximately 2,000 presentations as shown in Fig. 4 and the values of the learning rate and the momentum factor are determined as 0.1 and 0.2 through learning experience, respectively. 
[Table 1] Experimental Conditions of ANN models

\begin{tabular}{|c|c|c|c|c|}
\hline $\begin{array}{c}\text { ANN } \\
\text { Model }\end{array}$ & $\begin{array}{c}\text { Input } \\
\text { Pattern }\end{array}$ & $\begin{array}{c}\text { Output } \\
\text { Pattern }\end{array}$ & $\begin{array}{c}\text { Training } \\
\text { Pattern }\end{array}$ & $\begin{array}{c}\text { ANN } \\
\text { No. }\end{array}$ \\
\hline $\begin{array}{c}\text { Single } \\
\text { Model }\end{array}$ & $\begin{array}{l}\text { - DG output } \\
\text {-Total Current } \\
\text {-Active Power } \\
\text { of each feeder }\end{array}$ & $\begin{array}{c}\text { Levelized } \\
\text { Impedance }\end{array}$ & 320 & 1 \\
\hline $\begin{array}{c}\text { Separate } \\
\text { Model }\end{array}$ & $\begin{array}{c}\text {-Total Current } \\
\text {-Active Power } \\
\text { of each Feeder }\end{array}$ & $\begin{array}{c}\text { Levelized } \\
\text { Impedance }\end{array}$ & 64 & 5 \\
\hline
\end{tabular}

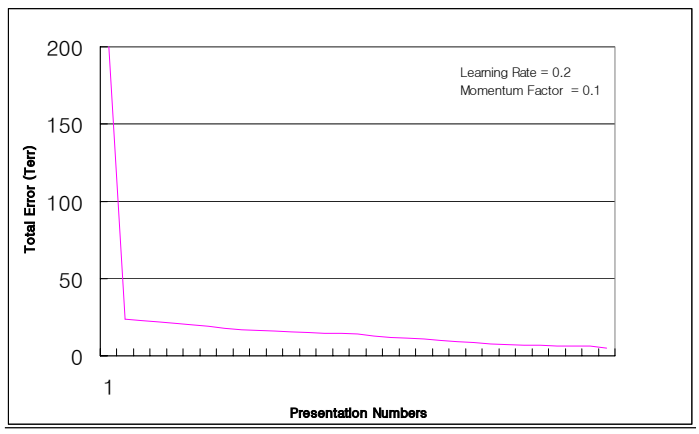

[Fig.4] Iteration number of ANNs

\section{Numerical Examples}

\subsection{Performance Index}

The criteria of the customer voltage distributions according to the operation of DG systems can be evaluated by the degree of how close customer voltages are maintained to the nominal voltage. Therefore, a performance index can be defined as a form of the squared differences between the nominal voltage and customer voltages of all nodes as follows:

$$
P I(t)=\sum_{k=1}^{K}[V 1(t, k)-V s t d]^{2}+[V s t d-V 2(t, k)]^{2}
$$

where, $\mathrm{PI}(\mathrm{t})$ is a performance index of time interval $\mathrm{t}, \mathrm{K}$ is the total number of nodes, $\mathrm{V} 1(\mathrm{t}, \mathrm{k})$ and $\mathrm{V} 2(\mathrm{t}, \mathrm{k})$ are the first and last customer voltages of each node and is the nominal voltage $(101 \mathrm{~V})$. It is clear that the customer voltage distributions become better with the smaller value of PI(t).

\subsection{Modeling Parameters}

(1) Fig. 5 and Table 1 show a model $22.9 \mathrm{kV}$ distribution system and a section data for primary feeders, respectively.

(2) The load patterns of $100 \sim 20 \%$ load rates based on the 45MVA are assumed as shown in Fig. 6, which represent a ratio of the hourly load to the peak load.

(3) The voltage drops of the pole transformer, secondary feeder and lead wire at the peak load are $4.0 \mathrm{~V}, 8.0 \mathrm{~V}$ and $4.0 \mathrm{~V}$, respectively.

(4) The voltage profiles of primary feeders can be calculated by the load flow of the Gauss-Seidel method. And the standard tap changing points of pole transformers are considered as 5\% voltage drop at the peak load on the basis of $22.9 \mathrm{kV}$.

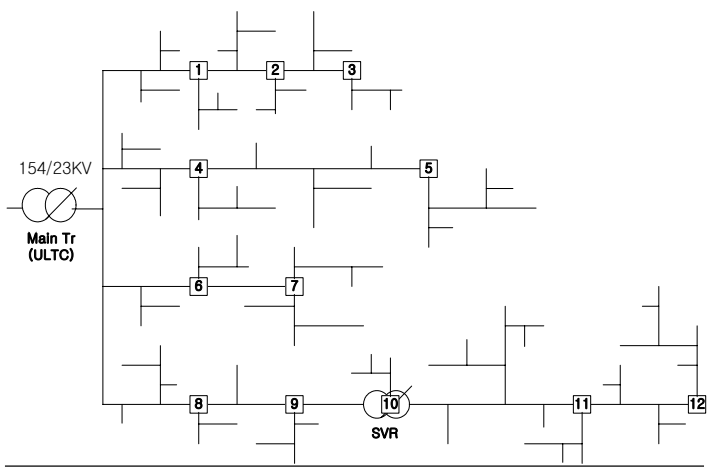

[Fig.5] Model distribution systems

[Table 2] Section data for primary feeders

\begin{tabular}{|c|c|c|c|c|c|c|c|c|}
\hline \multirow{2}{*}{$\begin{array}{l}\text { Feeder } \\
\text { Nimber }\end{array}$} & \multirow{2}{*}{$\begin{array}{l}\text { Section } \\
\text { Nmber }\end{array}$} & \multicolumn{2}{|c|}{ Node Nimber } & \multicolumn{2}{|c|}{ Impedance } & \multirow{2}{*}{$\begin{array}{l}\text { Length } \\
\text { (linl) }\end{array}$} & \multirow{2}{*}{$\begin{array}{c}\text { Pole Tr. } \\
\text { Tap }\end{array}$} & \multirow{2}{*}{ Load(\%) } \\
\hline & & From & To & $\mathrm{R}(\Omega / \mathrm{lm})$ & $\mathrm{X}(\Omega / \mathrm{ln})$ & & & \\
\hline \multirow{3}{*}{1} & 1 & 0 & 1 & 0.182 & 0.391 & 2.0 & $22900 / 230$ & $5 \%$ \\
\hline & 2 & 1 & 2 & 0.182 & 0.391 & 2.0 & 22900/230 & $10 \%$ \\
\hline & 3 & 2 & 3 & 0.182 & 0.391 & 5.0 & 22900/230 & $10 \%$ \\
\hline \multirow{2}{*}{2} & 4 & 0 & 4 & 0.182 & 0.391 & 5.0 & 22900/230 & $10 \%$ \\
\hline & 5 & 4 & 5 & 0.304 & 0.440 & 10.0 & $21400 / 230$ & $15 \%$ \\
\hline \multirow{2}{*}{3} & 6 & 0 & 6 & 0.182 & 0.391 & 4.0 & 22900/230 & $15 \%$ \\
\hline & 7 & 6 & 7 & 0.182 & 0.391 & 4.0 & 22900/230 & $10 \%$ \\
\hline \multirow{5}{*}{4} & 8 & 0 & 8 & 0.182 & 0.391 & 3.0 & 22900/230 & $5 \%$ \\
\hline & 9 & 8 & 9 & 0.182 & 0.391 & 5.0 & $22900 / 230$ & $5 \%$ \\
\hline & 10 & 9 & 10 & 0.182 & 0.391 & 5.0 & 22900/230 & $5 \%$ \\
\hline & 11 & 10 & 11 & 0.304 & 0.440 & 10.0 & $21400 / 230$ & $5 \%$ \\
\hline & 12 & 11 & 12 & 0.304 & 0.440 & 5.0 & $21400 / 230$ & $5 \%$ \\
\hline
\end{tabular}




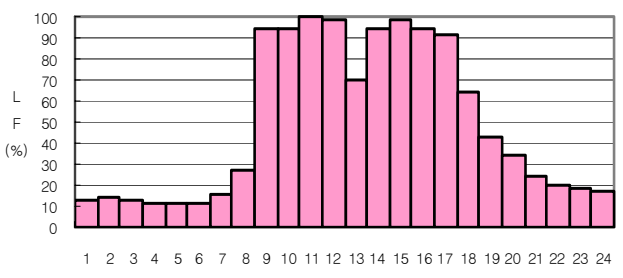

[Fig. 6] Daily load curve of main transformer

\subsection{Simulation Results}

For the control strategy evaluation of this study, we use the model system of Fig.5, Fig.6 and Table 2 and perform the simulation under the assumption that three load types vary randomly between $40 \%$ and $100 \%$ of the peak load. In the training data represents 64 load patterns (time intervals) of the case where DG systems are not operated $10 \%$ of the rated output. The performance index indicates that the single-type ANN model can not have proper pattern recognition capability, whereas the separate-type ANN model ismore effective on the on-line real time voltage regulation. We will thus concentrate on the separate-type ANN model from now on. Fig. 7 shows the sending voltages by the ideal method and by the responses of the ANN method presented. Fig.8 (a) shows the performance index of the ANN and the existing LDC (modified) method, and the time intervals of $1 \sim 10$, 11 20 and 21 30 represent the case where DG systems are operated as $0 \%, 50 \%$ and $100 \%$ of the rated output, respectively. Fig.8 (b) is the comparison results of ideal, ANN and modified methods for the case where DG systems is not operated. This figure shows that PI values of the ANN method have reasonable distributions through the entire time intervals, however, those of the modified method have unreasonable characteristics in proportion to the increase of load (decrease of time interval) since the setting values are determined as the smaller ones according to the peak cut operation of DG systems.

In addition, Fig.9 shows the customer voltage distributions of the ANN and modified methods. From the simulation results, the customer voltage distribution by the ANN method presented is greatly improved and maintained with more suitable conditions in comparison to that of the modified method. Thus, it is verified that the on-line real time method using the neural networks can improve the voltage compensation capability.
[Table 3] Evaluation results of ANN models

\begin{tabular}{|c|c|c|}
\hline \multirow{2}{*}{ ANN Model } & \multicolumn{2}{|c|}{ Performance Index } \\
\cline { 2 - 3 } & $\begin{array}{c}\text { Training } \\
\text { data }\end{array}$ & $\begin{array}{c}\text { Non-Training } \\
\text { data }\end{array}$ \\
\hline Separate Model & 4845.9 & 4797.3 \\
\hline Single Model & 9206.3 & 8859.1 \\
\hline Ideal Method & 4762.1 & 4672.5 \\
\hline Modified Method & 5748.2 & 5534.9 \\
\hline
\end{tabular}

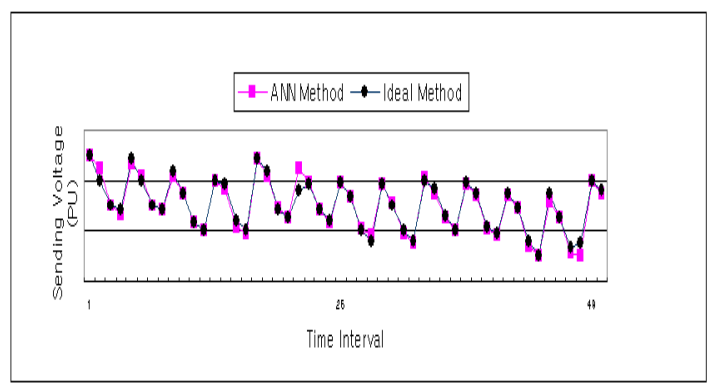

[Fig.7] Sending voltage by ANN and Ideal methods

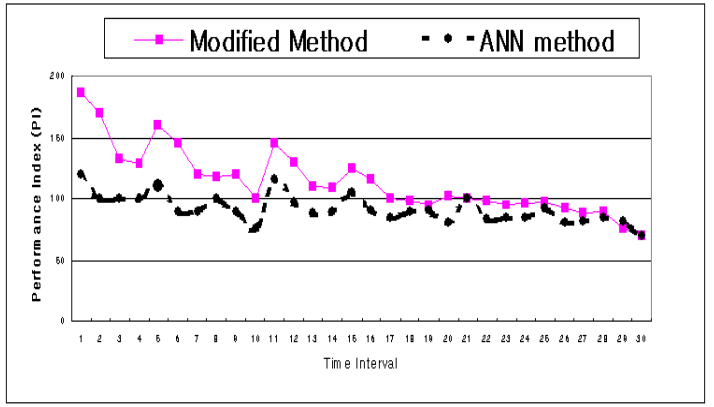

(a) Several outputs of DG systems

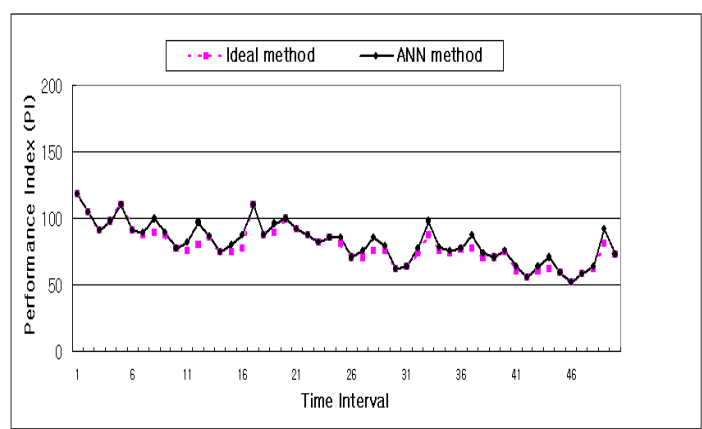

(b) $0 \%$ outputs of DG systems

[Fig.8] Performance index of each method 


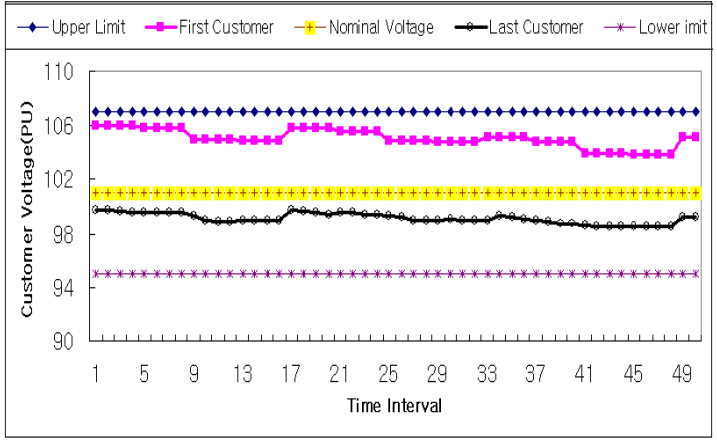

(a) Modified method

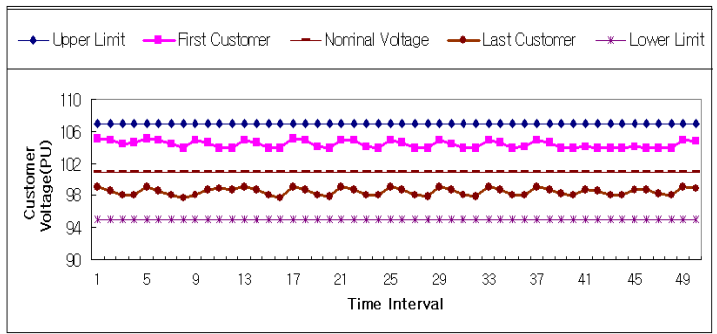

(b) ANN method

[Fig. 9] Customer voltage distributions

\section{Conclusions}

In this paper, the authors have discussed the effectiveness of an on-line real time voltage regulation method using neural networks. By comparison between the proposed method and the existing LDC method, their effectiveness was illustrated and demonstrated as follows.

(1) The customer voltage distributions by the proposed on-line real time voltage regulation method using the neural networks could than those of the existing LDC method

(2) It is also noted that the proposed on-line real time voltage regulation method using the separate -type neural network model has an appropriate pattern recognition capability within the possible training boundary and improves the voltage compensation capability of LRT in distribution substations.

The ANN method presented has the capability to feedback customer voltage conditions to the voltage regulators of distribution systems. This method can be expected to perform one of the functions of the Distribution Automation. Further, it can be expected that the ANN method will be more effective in the future as the telemetering device and budget are resolved.

\section{References}

[1] NREL, "Distributed Power Program DER Pilot Test at the Nevada Test Site ", NREL/TP 560-32063, 2002.5

[2] EPRI, " Electricity Technology Roadmap, Meeting the Critical Challenge of the $21^{\text {st }}$ Century", Product No. 10100929, 2003

[3] R. Grunbaum, "SVC Light: A Powerful Means for Dynamic Voltage and Power Quality Control in Industry and Distribution", Power Electronics and Variable Speed Drives, pp. 404-409, 18-19 September 2000, Eighth International Conference Publication No.475 @ IEE 2000.

[4] V. Karasik, K. Dixon, C. Weber, B. Batchelder, G. Campbell, and Ribeiro, "SMES for Power Utility Applications: A Review of Technical and Cost Considerations," IEEE Trans. Applied Superconductivity, Vol.9,No.2,June1999.

[5] H.Kirkham \& R.Das, "Effects of Voltage Control in Utility Interactive Distributed Generation", IEEE Trans. Power Apparatus and Systems, Vol. PAS-103, No.8, 1984

[6] H. Lee Willis, "Power Distribution Planning Reference Book", Marcel Dekker, Inc. pp. 185-228 (1997)

[7] D.Rho, J.Kim, "A Study on the Evaluation Algorithm of Distribution Systems Interconnected with Dispersed Generations", Trans. KIEE. Vol 56, No. 11, 2007

[8] D.Rho, J.Kim, "A Study on the Optimal Method for Mal-function of Re-closer at the Distribution Feeders Interconnected with Dispersed Generations", Trans. KIEE. Vol 58, No. 8, 2009

[9] H.Soi, H. Yakabe, H.Kakimoto, T.Hayashi \& M.Kanori, "Development of High Voltage Distribution Line Management System", IEEJP \& Society, No.32 (2006)

[10] 노대석 외 2인, "분산전원이 연계된 배전계통의 양방향 구간개폐기의 동작 알고리즘 연구", 한국산학기술학회논 문지, 제 10 권 8 호, 2009.8

[11] 노대석 외 3 인, "태광발전이 연계된 배전계통에서 보호협 조기기의 오동작에 대한 최적방안 연구", 한국산학기술학 회논문지, 제 9권 6호, 2008.6 
노 대 석(Dae-Seok Rho)

[정회원]

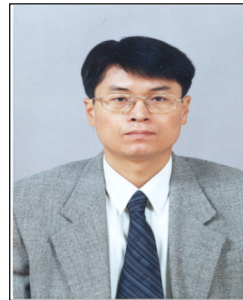

- Feb. 1985 : Electrical Eng, Hanyang Univ.(B.S.)

- Feb. 1987 : Electrical Eng, Hanyang Univ.(M.S.)

- Mar. 1997 : Electrical Eng, Kyoto Univ.(Ph.d)

- Mar. 1987 Jul. 1998 : Senior Researcher, KERI

- Feb. $1999 \sim$ current : Associate Professor, Korea University of Technology \& Education

$<$ Research Interests $>$

Distribution Power System, Dispersed Power Sources, Power Quality

\section{김 의 환(Hwan-Eui Kim)}

[정회원]

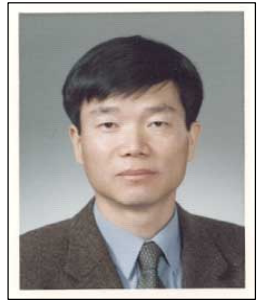

- Feb. 1996 : Mechanical Eng, Chungnam Univ. (M.S.)

- Feb. 2001 : Mechanical Eng, Chungnam Univ. (Ph.d)

- Mar. $1995 \sim$ Feb. 2006 : Senior Researcher, KEPRI

- Mar. $2006 \sim$ current : Principal Researcher, KEPRI

$<$ Research Interests $>$

New Energy Sources, PV Systems 